\title{
Supply chain management, supply chain flexibility and firm performance: An empirical investigation of agriculture companies in Indonesia
}

\author{
Itang $^{\text {a }}$, H.S. Sufyati ${ }^{\mathrm{b}}$, Asep Dadan Suganda ${ }^{\mathrm{a}}$, Shafentic ${ }^{\mathrm{c}}$ and Mochammad Fahlevi ${ }^{\mathrm{d}^{*}}$
}

${ }^{a}$ UIN Sultan Maulana Hasanuddin Banten, Indonesia

${ }^{b}$ Universitas Pembangunan Nasional Veteran Jakarta Prodi Ekonomi Syariah, Indonesia

${ }^{c}$ Akademi Akuntansi YAI, Indonesia

${ }^{d}$ Management Department, BINUS Online Learning, Bina Nusantara University, Indonesia 11480

\section{A B S T R A C T}

\begin{tabular}{l}
\hline Article history: \\
Received June 18, 2021 \\
Received in revised format July \\
20,2021 \\
Accepted October 22021 \\
Available online \\
October 32021 \\
\hline Keywords: \\
Supply Chain Management \\
Supply Chain Flexibility \\
Competitive Advantage \\
Firm Performance
\end{tabular}

\section{Introduction}

Corn is the second main food commodity after rice grown by farmers throughout the archipelago. Corn has long been used as a raw material for making feed. Apart from being relatively cheap, corn also contains relatively high calories, contains complete protein and amino acids, is easy to produce in large quantities, and is very popular with (Cheng et al., 2015). In addition, corn is also a staple food for most Indonesian people (Rusastra \& Saliem, 2004). Corn production in 2018 (ARAM I) is estimated to reach 30.06 million tons, an increase of $3.91 \%$ from the previous year. This increase is the highest increase in the last 5 years. The increase in corn production in 2018 was more influenced by an increase in harvested area of 201.16 thousand hectares (3.64\%) while an increase in productivity of $0.14 \mathrm{ku} / \mathrm{ha}(0.27 \%)$. During the period $2014-2018$, maize production growth outside Java was higher than growth in Java. Corn production growth in Java is only $6.13 \%$ per year, while outside Java is $36 \%$ per year. The high growth of maize production outside Java is mainly due to the growth of harvested area. Competition for land use in Java, especially between rice and secondary crops can be the main reason for the slow increase in maize production in Java. This condition shows by building irrigation infrastructure and better roads, followed by the introduction of innovations. production technology that is even more aggressive to corn farmers outside Java, it is not impossible that maize productivity outside Java will be the same, even higher than Java (Kementan, 2018).

* Corresponding author

E-mail address: mochammad.fahlevi@binus.ac.id (M. Fahlevi)

(C) 2022 Growing Science Ltd. All rights reserved.

doi: $10.5267 /$ j.uscm.2021.10.001 
To meet the needs of corn in various regions, it is necessary to have a good distribution from the producer level to the consumer level, this distribution is called the supply chain. Distribution starts from the side of the farmer as a producer who then sells his goods to collectors. The collectors then distribute the corn to the agriculture company and after that it is sent to the final consumer to the animal feed factory. This is because the management of farming using the agribusiness approach is increasingly being implemented, with the hope that the farming must be managed with a variety of resources that are quite effective and efficient. According to Saragih et al. (2009), without effective and efficient farming it is impossible to build an agribusiness system or a process to increase the added value of farmers' resources that is stronger. The technology used for this does not only cover the technical field of farming, but also includes processing and distribution technology, to produce agricultural products that are highly competitive in the market and have a positive impact on the local (rural) community economy. Policies that can answer problems in the agricultural sector are addressing farmers' problems with capital and ease of accessing that capital (Adam et al., 2012). Close to 90\% of corn comes from ten agriculture center provinces in Indonesia, namely East Java, Central Java, Lampung, South Sulawesi, North Sumatra, West Java, West Nusa Tenggara, Gorontalo, East Nusa Tenggara and West Sumatra. While the provincial centers as agriculture users are represented by the number of feed factories, but not all of them are in the provinces of agriculture production centers. In fact, the spread of corn production is an obstacle for the industry in collecting the corn production. This is because it requires large operational costs. Problems in the supply chain that take a long process and expensive logistics costs will have an impact on the cost of buying corn to be more expensive. In the end it is charged to the price of corn received by farmers to be cheaper. This is the reason feed mills prefer to import corn. One of their main reasons is that corn imports are more cost effective than corn which is spread from corn centers to corn usage centers. The impact of these import policies and options has an impact on the domestic price of corn and what farmers receive is lower, in the end farmers are less interested in growing corn.

The company's competitiveness will improve when the technological innovations applied by agriculture farmers are also more advanced. By considering these comparative advantages, Indonesia's future corn production will not only meet domestic needs. It is more important to make corn the mainstay of export commodities. The problem is that not all domestic corn meets the specifications required by the manufacturer, especially the high alpha toxin content in domestic corn (Subhana, 2005). In addition, the water content of domestic corn does not meet the production requirements for animal feed raw materials where domestic corn has high water content and the storage system is not good so that domestic corn has mold and cannot be stored for the period required by the factory. Even though the demand for corn for industry is very high. Competitiveness through innovation is applied by companies with more efficient and modern postharvest processing methods so that corn can be stored and transported without neglecting the side of good quality maintenance. The performance of the agriculture companies also depends on the increase in the volume of corn production at the farmer level. The challenge of productivity apart from the supply chain path is the limited availability of water on dry land. With the limited absorption from animal feed, on the other hand the company must absorb corn to produce higher firm performance even though they must deal with space limitations. during the peak harvest season, so that the company can facilitate the needs of animal feed both during the main harvest and non-harvest seasons, balanced by having adequate drying and storage facilities. Agriculture companies play an important role in the price of corn in Indonesia. Companies are being pushed to achieve the greatest results as corporate competition becomes more intense. In order to generate economic value for the firm that is superior to competitors, companies must be able to develop competitive advantage (Hesterly \& Barney, 2008). The ability of a business to identify, use, and absorb internal and external resources and information to support overall supply chain activities is referred to as supply chain capability (Bharadwaj, 2000). By connecting essential business activities from end users to suppliers and vendors, supply chain skills can help partners gain a competitive edge and improve business performance (Kristal et al., 2010). It entails the coordination of operations relating to the flow of commodities from the raw materials stage to the end user, as well as the corresponding information flow both up and down the supply chain. The ability of a company to develop certain capabilities and competitiveness, seek total supply chain coordination, improve communication to reduce uncertainty and inventory levels, ensure timely delivery of high-quality goods and services at reasonable costs, and proper engagement of business partners are all necessary for Supply Chain Management to succeed as a system (Acharyulu \& Shekbar, 2012).

Companies must apply supply chain management to improve industrial competitiveness, which has an impact on firm performance. To ensure that supply chain management supports the company's strategy, companies must evaluate supply chain concerns (Heyzer \& Render, 2001). To gain a competitive advantage in the market, businesses must develop competitive advantages. In today's increasingly tough competition, every company's major goal is to become a leader. Companies are being pushed to achieve the greatest results as corporate competition becomes more intense. In order to generate economic value for the firm that is superior to competitors, companies must be able to establish competitive advantages (Hesterly \& Barney, 2008). Companies must use supply chain management to its full potential. Because supply chain management can generate a company's competitive edge, it can help to lessen the effects of market rivalry. Companies can gain a competitive advantage by managing their supply chains effectively. Because supply chain management can reduce the entire cost of fulfilling and serving consumer needs, the company outperforms competitors. All parties involved in executing consumer orders and requests, whether directly or indirectly, are included in supply chain management (Chopra \& Meindl, 2001). Producers and suppliers aren't the only ones participating; distributors, storage facilities, sellers, and customers are also involved. The strategy of the company is employed in the development of the company's operations 
to compete and dominate the market's current position. The company's competitive advantage plan should allow it to preserve its competitive position in the face of competition while also allowing it to improve its performance in line with its goals (Ilmiyati \& Munawaroh, 2016). According to Li et al. (2006) report, good supply chain management can help businesses gain a competitive advantage. It has been demonstrated that by integrating supply chain management, starting with relationships with suppliers and customers, delays, and quality, a company can maintain and increase its competitiveness in the market. Pramana (2016) indicates that the influence of supply chain management via indirect and direct approaches yields the finding that supply chain management has a stronger influence if it is achieved through competitive advantage or indirectly. These findings support the contention that the competitive advantage theory can mitigate the impact of supply chain management on firm performance.

There is also a previous study by Yunas et al. (2016) regarding the analysis of the influence of supply chain management and supply chain strategy through competitive advantage affecting company performance, but the subject of the research was conducted on the cacao company industry. In the cost structure of chicken meat production, feed is the largest part of production costs, reaching $70 \%$. Meanwhile, the portion of corn in the manufacture of animal feed, especially broilers, is more than $50 \%$. This is the reason why the demand for corn is increasing along with the increasing demand for livestock products such as eggs, meat, and milk. Therefore, the application of SCM in terms of providing sufficient corn from domestic production is very important in supporting the development of the animal feed industry in Indonesia. The life and death of the animal feed industry in Indonesia is largely determined by the performance of corn production. This means that the availability of sufficient domestic corn is very important in supporting the development of the performance of agriculture companies in Indonesia. To keep pace with the ever-increasing demand, efforts to stimulate domestic production, both by expanding the planting area and increasing productivity, are important. With the increase in production, corn imports will be reduced, even non-existent. The rapid increase in demand for corn from the feed mills shows that people's incomes are getting better. This also encourages the increase in protein consumption of chicken meat and eggs. To protect the livestock and feed industry in Indonesia, efforts to provide as much corn as possible from within the country are the main choice. Therefore, breakthrough innovations to reduce production costs and increase productivity and quality of corn must receive important attention. From the literature search, researchers have not found any published studies or articles on SCM and SCF in their influence on company performance through competitive advantage, specifically for agriculture companies in Indonesia (Sutia et al., 2020).

\section{Methodology}

This study was conducted to examine the influence of supply chain management on firm performance through competitive advantage and to measure the relationship, influence, and magnitude of the influence of independent variables (supply chain management and supply chain flexibility) and mediating variables (competitive advantage) on the dependent variable (company performance). Therefore will be used correlation test and multiple linear regression (Lind et al., 2018). The population in this study is agriculture companies in Indonesia. Sampling was carried out using probability sampling technique, which is a sampling technique that provides equal opportunities or opportunities for each member of the population to be selected as a sample (Saunders et al., 2009). There are several methods in probability sampling, in this study the method used is Simple Random Sampling where part of each population has the same opportunity to be sampled. So that this research can be generalized. The number of samples in this study will be determined using the slovin formula (Slovin et al., 1993). Thus, the total population of 200 obtained a sample size of 133.333 which can be rounded up to 134 research samples (Sekaran \& Bougie, 2016). The path analysis created in this study employs a complex model, necessitating the usage of an analytical tool capable of explaining the relationship. The Partial Least Square Version 3 program was employed in the data analysis of this study as an inferential statistical method. The author employs reflexive indicators in this investigation. A reflexive indicator is a construct that expresses the observable as a function of the construct (the item reflects or is a manifestation of the construct) (Hair et al., 2017). This study consists of four variables where there are two exogenous variables and two endogenous variables, namely supply chain management and supply chain flexibility as exogenous variables and competitive advantage and company performance as endogenous variables. The table below explains the basis for measuring each variable according to the dimensions that have been formulated by previous experts or researchers to measure these variables (Hair et al., 2017).

\section{Table 1}

Measurement

\begin{tabular}{ll}
\hline Variables & Source \\
\hline Supply Chain Management $(X 1)$ & Li et al. (2006) \\
Supply Chain Flexibility $(X 2)$ & Pujawan (2004) \\
Competitive Advantage $(M)$ & Li et al. (2006) \\
Firm Performance $(Y)$ & Al-Matari et al. (2014) \\
\hline
\end{tabular}

Source: (Al-Matari et al., 2014; Li et al., 2006; Pujawan, 2004) 


\section{Result and Discussion}

Before analysing the path model and evaluating the hypothesis, the validity of each indicator is evaluated using the Smart PLS 3 program in the next stage. If one indicator has a loading value of 0.5 with the latent variable to be measured, the indicator must be discarded because it shows that the indicator is not good enough to measure the latent variable reliably (Hair et al., 2017). The following are the results of the output factor loading construct of each variable in PLS:

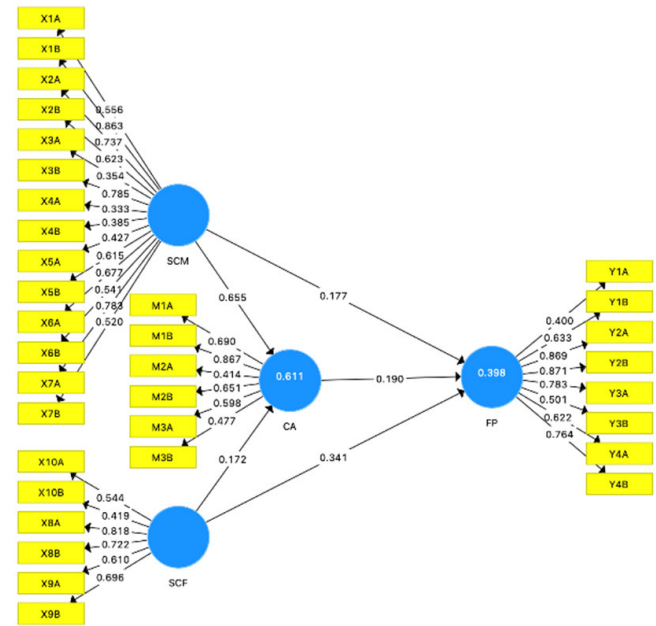

Fig. 1. Structural Equation Model

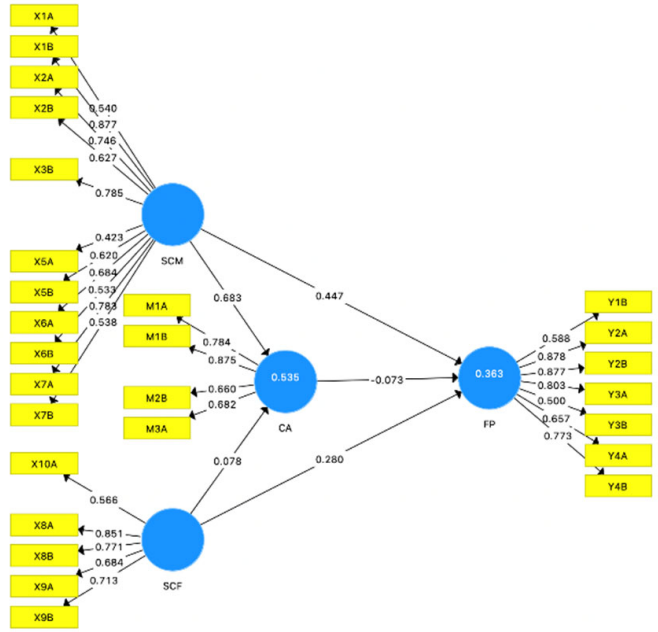

Fig. 2. Modification Model

Based on the loading factor value above, almost all research indicators have a high convergent validity value, where the indicator has a loading factor above 0.5 and is significant, but indicators that have a low loading factor will be deleted (Hair et al., 2017). In research, a variable is said to be quite reliable if the variable has a construct reliability value greater than 0.7 . The following is a table of the results of reliability testing on each research variable. In the reliability test, it will be seen from the value of Cronbach's alpha and composite reliability.

\section{Table 2}

The results of the reliability

\begin{tabular}{lcc}
\hline Variables & Composit Reliability & Cronbach Alpha \\
\hline Supply Chain Management $(X 1)$ & 0.893 & 0.864 \\
Supply Chain Flexibility $(X 2)$ & 0.843 & 0.772 \\
Competitive Advantage $(M)$ & 0.840 & 0.747 \\
Firm Performance $(Y)$ & 0.890 & 0.854 \\
\hline
\end{tabular}

Based on the reliability output above, it can be determined that all research variables have a reliability composite and a Cronbach's alpha of greater than 0.7 , and that the indicators employed in each variable have strong reliability or can measure constructs. This means that the number indicates that every construct in this model has passed the reliability test, allowing it to proceed to the next analysis test.

Table 3

Model Summary

\begin{tabular}{ll}
\hline Variables & R Square \\
\hline Competitive Advantage & 0,535 \\
Firm Performance & 0,363 \\
\hline
\end{tabular}

In Table 3 , it is known that the r-square value for the competitive advantage variable is 0.535 or $53.5 \%$. This indicates that the exogenous variables, namely SCM and SCF, can explain the competitive advantage variable of $53.5 \%$. This value is quite high because it is more than $50 \%$. In the firm performance variable, it is known that the r-square value of 0.363 or $36.3 \%$ shows that the exogenous SCM and SCF variables as well as the competitive advantage mediating variable are able to explain the firm performance variable of $36.3 \%$, this value is smaller than the previous value in competitive advantage. In testing the hypothesis in this study, the path analysis value was used for each direct effect path. The following is an image explaining the path diagram for hypothesis testing: 


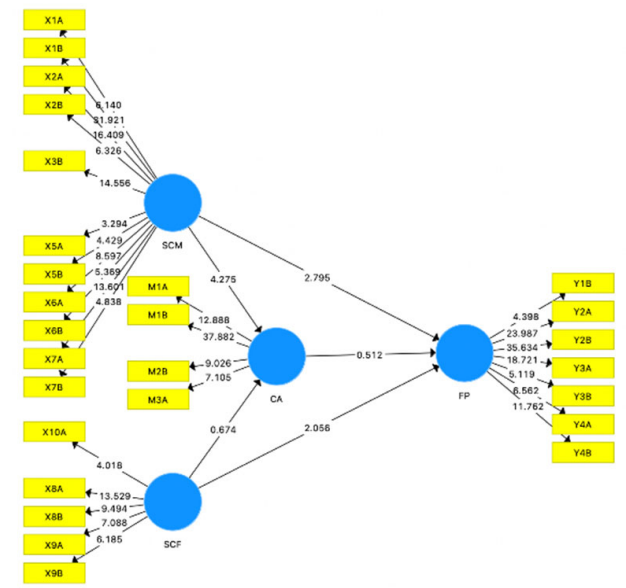

Fig. 3. Bootstrapping

All indicators on each variable have a statistical value larger than 1.96, indicating that this indicator can measure each construct, according to the hypothesis testing path diagram above. Meanwhile, the statistical value of the Smart PLS output is compared to the table value to test the association between variables (hypothesis testing) (Hair et al., 2017). The following is a table that provides the results of the relationship between the constructs.

\section{Table 4}

Hypothesis

\begin{tabular}{llccc}
\hline No & Hypothesis & Original Sample & Standard Deviation & T-Statistics \\
\hline 1 & SCM $\rightarrow$ FP & 0.447 & 0.160 & 2.795 \\
2 & SCF $\rightarrow$ FP & 0.280 & 0.136 & 2.056 \\
3 & SCM $\rightarrow$ CA $\rightarrow$ FP & -0.050 & 0.114 & 0.005 \\
4 & SCF $\rightarrow$ CA $\rightarrow$ FP & -0.006 & 0.019 & 0.439 \\
\hline
\end{tabular}

In the results of the first hypothesis in this study, it accepts hypothesis one and these results are supported by research Handoko et al. (2015) says that supply chain management has a direct influence on firm performance, this can be different from previous research because in the research conducted by Handoko et al. (2015), it is known that researchers conducted research in manufacturing companies. The sector difference between previous studies that discussed a lot about the manufacturing sector is that in the food sector, SCM has a significant influence on firm performance because the firm performance in corn processing is heavily influenced by macro factors that affect food prices and government policies regarding food and supply of goods. This greatly affects the firm performance. The sample companies in this study are only in charge of processing corn ingredients and not on corn production so that supply chain management has significant influence. The second hypothesis in this study is accepted and in accordance with research conducted by Pujawan (2004) that supply chain flexibility has a significant influence on firm performance directly through company processes in meeting customer or consumer needs, but previous research was dominated by research conducted on companies. manufacturing, besides the main problem is that there is no agreement on the right dimensions in measuring flexibility so that researchers only use dimensions that are considered appropriate to the object of research, in the case of this study researchers use three dimensions that have a relationship with food companies, especially agriculture companies that do not produce corn but processing corn produced by farmers and making finished goods that will be sold directly to consumers. On the dimensions and loading factors, we can see that processing flexibility has the greatest influence, so we can conclude that processing at an agriculture company that does process corn has the most important level in determining the effect on firm performance. In the third and fourth hypotheses, it is known that the competitive advantage variable does not succeed in being a mediator in SCM and SCF on firm performance. This result is related to the business climate of agriculture companies in Indonesia, which are still few, and many companies do not produce their own food but import from other countries so that the climate of competition between companies is very small.

\section{Conclusion}

The performance of agriculture companies depends on increasing the volume of corn production at the farm level. Productivity challenges apart from the supply chain path, the limited availability of water on dry land, most of the farming is still done manually, so production costs are expensive. Drying places at the farm level are also limited. This is one of the biggest challenges for corn processing companies in Indonesia. This study found that SCM influences firm performance and SCF has a direct influence on firm performance. Competitive advantage variable fails in being a mediator in SCM and SCF on firm performance. Agriculture companies need to carry out SCM and SCF well, both of which can answer the challenges faced by agriculture companies in Indonesia based on previous research that good implementation of SCM and SCF will improve the performance of agriculture companies. Competitive advantage needs to be developed as in this study 
SCM, which through and supported by competitive advantage, can have a significant effect on firm performance. It is hoped that agriculture companies can implement the results of this research as an effort to improve the performance of agriculture companies in Indonesia. Further researchers are expected to use various analytical methods to enrich further research and it is recommended to use a larger sample and be supported by qualitative data. In business practices, companies must increase flexibility in the supply chain so as to increase competitive advantage and firm performance because the path analysis model using PLS over SCF has the highest value and high level of influence compared to other variables.

\section{References}

Acharyulu, G., \& Shekbar, B. R. (2012). Role of value chain strategy in healthcare supply chain management: An empirical study in India. International Journal of Management, 29(1), 91.

Adam, L., Data, P. P. P., \& RI, I. S. J. D. (2012). Urgensi pembentukan bank pertanian Indonesia.

Al-Matari, E. M., Al-Swidi, A. K., \& Fadzil, F. H. B. (2014). The measurements of firm performance's dimensions. Asian Journal of Finance \& Accounting, 6(1), 24.

Bharadwaj, A. S. (2000). A resource-based perspective on information technology capability and firm performance: An empirical investigation. MIS Quarterly, 169-196.

Cheng, S.-F., Huang, C.-Y., Lin, Y.-C., Lin, S.-C., \& Chen, K.-L. (2015). Phytoremediation of lead using corn in contaminated agricultural land-An in situ study and benefit assessment. Ecotoxicology and Environmental Safety, 111, $72-77$.

Chopra, S., \& Meindl, P. (2001). Strategy, planning, and operation. Supply Chain Management.

Hair, J. F., Hult, G. T. M., Ringle, C. M., \& Sarstedt, M. (2017). A Primer on Partial Least Squares Structural Equation Modeling (PLS-SEM) (2nd ed.). Sage.

Handoko, B. L., Aryanto, R., \& So, I. G. (2015). The impact of enterprise resources system and supply chain practices on competitive advantage and firm performance: Case of Indonesian companies. Procedia Computer Science, 72, $122-128$.

Hesterly, W., \& Barney, J. (2008). Strategic management and competitive advantage.

Heyzer, J., \& Render, B. (2001). : Operation Management. New Jersey (US): Prenyice Hall Inc.

Ilmiyati, A., \& Munawaroh, M. (2016). Pengaruh manajemen rantai pasokan terhadap keunggulan kompetitif dan kinerja perusahaan (Studi pada usaha kecil dan menengah di Kabupaten Bantul). Jurnal Manajemen Bisnis, 7(2), $226-251$.

Kementan, B. (2018). Peta Ketahanan dan Kerentanan Pangan Indonesia (A Food Security and Vulnerability Atlas of Indonesia).

Kristal, M. M., Huang, X., \& Roth, A. V. (2010). The effect of an ambidextrous supply chain strategy on combinative competitive capabilities and business performance. Journal of Operations Management, 28(5), 415-429.

Li, S., Ragu-Nathan, B., Ragu-Nathan, T., \& Rao, S. S. (2006). The impact of supply chain management practices on competitive advantage and organizational performance. Omega, 34(2), 107-124.

Lind, D. A., Marchal, W. G., \& Wathen, S. A. (2018). Statistical Techniques in Business \& Economics (17th ed., p. 897). McGraw Hill Education.

Pramana, Y. K. (2016). Analisa Pengaruh Supply Chain Management terhadap Keunggulan Bersaing dan Kinerja Perusahaan Manufaktur di Jawa Timur. CALYPTRA, 4(2), 1-19.

Pujawan, I. N. (2004). Assessing supply chain flexibility: A conceptual framework and case study. International Journal of Integrated Supply Management, 1(1), 79-97.

Rusastra, I. W., \& Saliem, H. P. (2004). Prospek pengembangan pola tanam dan diversifikasi tanaman pangan di Indonesia.

Saragih, E. S., Sitorus, S. R., \& Moeljopawiro, S. (2009). Analisis Kelayakan Ekonomi, Keberlanjutan Usahatani dan Faktorfaktor Penentu Adopsi Benih Jagung Transgenik di Indonesia. Jurnal Agro Ekonomi, 27(1), 23-44.

Saunders, M., Lewis, P., \& Thornhill, A. (2009). Research Methods for Business Students (5th ed.). Prentice Hall.

Sekaran, U., \& Bougie, R. (2016). Research methods for business: A skill building approach. John Wiley \& Sons.

Slovin, M. B., Sushka, M. E., \& Polonchek, J. A. (1993). The Value of Bank Durability: Borrowers as Bank Stakeholders. The Journal of Finance, 48(1), 247-266.

Subhana, A. (2005). Strategi pengembangan agribisnis jagung untuk memenuhi kebutuhan industri pakan peternak.

Sutia, S., Riadi, R., \& Fahlevi, M. (2020). The Influence of Supply Chain Performance and Motivation on Employee Performance. International Journal of Supply Chain Management, 9(2), 86-92.

Yunas, S., Primiana, I., Cahyandito, M. F., \& Kaltum, U. (2016). New model of competitive advantage of supply chain management practices a case of Indonesian CACAO manufacturing industry. International Journal of Economics, Commerce and Management, 4(9), 407-422.

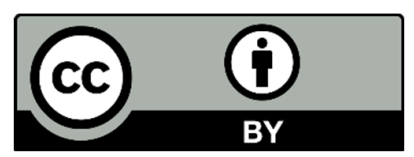

(C) 2022 by the authors; licensee Growing Science, Canada. This is an open access article distributed under the terms and conditions of the Creative Commons Attribution (CCBY) license (http://creativecommons.org/licenses/by/4.0/). 